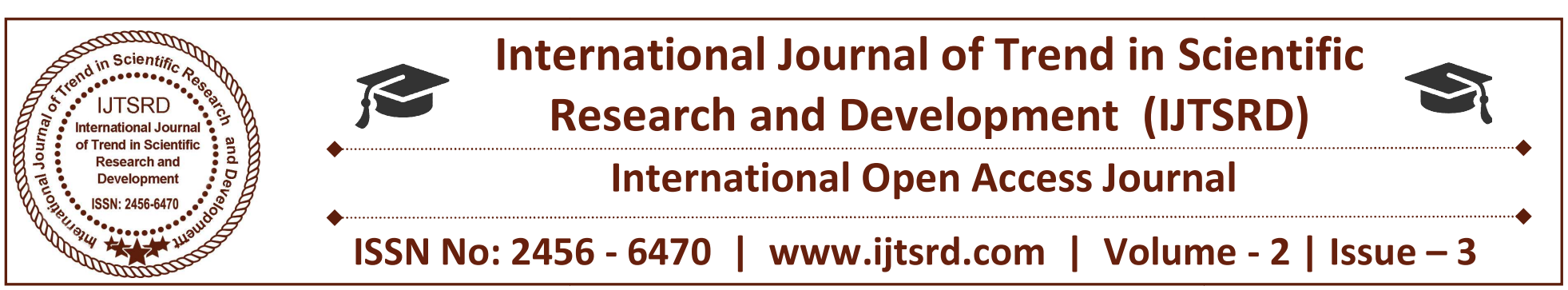

\title{
Division of Jane Austen Novels
}

\author{
B. Suganthi \\ MA, English, \\ Nadar Saraswathi College of Arts and Science, \\ Vadaputhupathi, Theni, Tamilnadu, India
}

\author{
K. Swarnamuki \\ MA English, \\ Nadar Saraswathi College of Arts and Science, \\ Vadaputhupathi, Theni, Tamilnadu, India
}

\section{ABSTRACT}

We have to understand Jane Austen's work better, we should learn something of the world in which her comparatively short life was passed and the conditions under which her novels were produced. Thought she was bred in the country and had a great love of natural scenery, her primary interest was in her own fellow-beings and among these, the members of her own family stood foremost. Thought she had many and frequent contacts with the outside world, she was never separated from her family, for any considerable period of time. Hers was a large family, the rector of Steventon being blessed with many sons and two daughters, and a very hospitable one. As a novelist of manners, Jane Austen laughs goodhumouredly at the weaknesses, vanities and foible of men women.

\section{INTRODUCTION}

Jane Austen was born the classical age had passed away. Formality in art, manners and ideas had given place to something which was emotional, imaginative and spontaneous. In poetry the stiffness of the heroic couplet had been replaced by the irregular verse forms. Pope and Addison had been dethroned as popular idols in favour of Cowper and Scott. Shakespeare had come back into his own after years of eclipse as a barbarian. In Jane Austen we have the critic of romance and of contemporary manner. Jane Austen, like her predecessors, fanny Burney, Maria Edgeworth and other women novelist of the period, exemplifies the feminine point of view in fiction.

\section{DRAMATIC NATURE OF HER NOVELS:}

Jane Austen is instinctively dramatic. Though her comedies are cast in the mould of Novels, she has employed the dramatic form. In the spirit and technique her novels are essentially dramatic. Baker has pointed out that plot of pride and prejudice is constructed like a drama. He proves it by dividing the story of the novel into five act of a drama. "As a novelist Austen employed the dramatic form evolved by fielding, but she refined it and gave it perfection. There are no digressions, no intrusions by the author; instead we are offered a completely life-like impression in which the movement of time is subtly controlled. She catches the dynamic moment which precipitates the crisis and then within the scope of her psychology allows the denouement to proceed according to plan."

Her characters are always in the process of development. They are in the process of self-delusion, awakening, disillusionment and reconciliation. Catherine Morland in Northanger Abbey, Marianne in sense and sensibility, Elizabeth in Pride and Prejudice and Emma in Emma a discover that they have been making mistakes both about themselves and about the world in which they live. "The point of view not merely of humour but of comedy is so marked in Jane Austen's novels as to suggest she is a good deal influenced by the drama"

\section{DRAMATIC IRONY}

Dramatic irony is used to describe the situation which arises when a character in a play speaks lines which are understood in a double sense by the audience. The characters do not understand the fill implication and 
signification of what they speak. The characters of Jane Austen like Emma and Elizabeth do not know the situation as it really is. And this amuses the readers. Irony proceeds out from the sense of contradiction felt by the spectators of a drama who see a character acting in ignorance of his condition. Mrs. Bennet never understands that her husband is making fun of her poor nerves.

Jane Austen also uses irony by jolting the readers out of their settle views. Just when we conclude in sense and sensibility that we should prefer Elinor's sense to Marianne's sensibility, Elinor bends towards the sensibility. Irony, as Baker point out, is the soul of Jane Austen novels. The comic aspects of life are ironical aspects. If we do not understand this we cannot understand Jane Austen.

\section{JANE AUSTEN AS A REALIST}

Jane Austen is an unswerving realist. The world of her novel is real and interesting, very much like our own. She has pointed only those scenes which she has herself seen. Her heroes and heroines make love and are married as we make love and are married. Unexpected good or ill fortunes of chances happen to prevent or bring out the happy results. She has described such people as meet together every day in every respectable house in London. Jane Austen who was possessed of common sense in the highest measure, was aware of her own limitations as a writer. Her knowledge of life being restrain to a small ring of regional civilisation, she was fairly satisfied to contract with that civilisation in her novels and was alert enough not to exceed the limitations of her own knowledge. Whether, we consider fanny's visit to her parent home, or Darcy's proposal to Elizabeth or the marriage of Emma with her lover, or such trivial incidents as a tea-party, an evening walk or a ball, we are struk by Jane Austen's fidelity to life. She has painted the surface of English life with a meticulous and the Dutch accuracy.

W.L.cross in his book, The Development of the English Novel, pays a fine tribute to Jane Austen's realism. He says: "Now when we come to bring together in a few sentences Jane Austen's contribution to fiction, it is quite clear what must be said. She was a realist. Though her realistic pictures are stark they not drab. They are lively and sparking. How close she comes to life that is stark without being drab can be seen from the fact that had not the incidents of provincial life been handled by a master hand they would not have been intrincically even worthy of notice in a newspaper. Jane Austen's style is the language of everyday life, even with a tinge of its slang, to which she had added an element of beauty.

\section{JANE AUSTEN AS A MORALIST:}

Jane Austen is not a moralist like Johnson. She never preaches morals, and remains untouched by reforming ardour. She is not a deliberate preacher who uses novel as a platform for gospel and reform. The spectacle of human ineptitude amused her too much for her to have any great wish to put an end to it. She wrote primarily to entertain. The novels on the didactic level, we find that Jane Austen's first published novel, sense and sensibility, is an instructive treatise on the desirability of sense and the danger of excessive sensibility, as seen from the charcters and fortunes of two sistes, Marianne Dashwood and Elinor Dashwood. Marianne's "scorching hominid soul" leads to soul disruption, disenchantment, and depression till she achieves intellect enough to marry the mature and pale colonel Brandon on sensible thoughts. Most things amused her; few things angered her. She greets those the dislikes with a silght. Contemptuous smile. She never rages at the follies and vices as Swift, Langland and Fielding do. This power of self-detachment makes her an artist pure and simple. There is no didacticism; no philosophy, no propaganda in her novels. As a novel of instruction, Emma deals with the faults of the heroine who is always wrong and always believes herself to be right. It is a kind of drawing-room comedy of self-deception. Emma in course of time gains self-knowledge and has an insight into one of her major failings. Leonie Villard says that Jane Austen is merely an amused and attentive spectator. She does not seek to interpret life. She is content to observe it. Thus interpreted Jane Austen's novels are merely the detached of her time and place. Professor Mudrick makes morality central of Jane Austen's art.

\section{JANE AUSTEN AS A NOVELIST OF MANNERS:}

Jane Austen's novels are characterized by an exquisite perfection which is the result of her being content to work in the limited field which she knew best. The range of Jane Austen is certainly limited in her novels. She a concise her work as "a little bit of ivory two inches wide". She presents a concise and concentrated texture. Her character can be seen doing their actions in a specified field and they are away 
from philosophical pondering and poetic effect. While reading her novels the readers feel like seeing a mingbowl in the hands of a potman. Her novels are called tea-cup dreams, and she controls tension in the miniature of tete-a-tete and tea cups. She has made a wonderful fine art. There are storms in the tea cups. She does not use a big canvas as used by Emily Bronet in the novel Wuthering Heights. Three of four families in a country village form the very stuff of work. Richard Church points out, "It was not that Jane Austen was unaware of what was happening. She was neither obtuse nor insensitive, as her early novels Northanger Abbey dhows, towards the excitements and heightened sensations which life and literature together were exploring at that time. But she was marvellous, being so young, that she could stand against the vast tide and not to be toppled over. Northanger Abbey is an ironic parody.... Of the Anne Radcliffe and Monk Lewis extravaganza, and in hitting at those practitioners, she was also containing an almost preconscious criticism of the times in which she lived."

\section{CONCLUSION:}

Jane Austen handles more closely the intricate plot, without the help of any sensational events. "To present her story", says W.A.Craik,"she returns to the method, practise in Sense and Sensibility and mastered in Pride and Prejudice." She goes on to state the inevitable of plot when she writer: "Austen appears much less in person as narrator because here we need to know scarcely anything that Emma cannot tell, us consciously or unwittingly, the unity of the plot and character is therefore much closer than ever before". In Sense and Sensibility is another quality of the constrictive genius of Jane Austen which we encounter in the course of the growth of the plot, and also the suspense which the readers are made to experience at various points.

\section{BIBLOGRAPHY}

M.K Srivastava - Jane Austen's Sense and Sensibility published by Lakshmi Narain Agarwal Educational publishers.

Mrs. Anna Kurian - Jane Austen's Emma published by Lakshmi Narain Agarawal Educational publishers.

$>$ Prof. Grish Saxena - Jane Austen's "Emma” A Critical study Published by Prakash Book Depot BARA Bazar bareillly. 